\title{
Development Supply Chain Management In Terms of Quality Function: An Application in the Manufacturing Industry
}

\author{
Ayşenur Erdil ${ }^{1 *}$ \\ 1* İstanbul Medeniyet University, Faculty of Political Sciences, Business Administration, İstanbul, Turkey (ORCID: 0000-0002-6413-7482)
}

(3rd International Congress on Human-Computer Interaction, Optimization and Robotic Applications June 11-13, 2021)

(DOI: $10.31590 /$ ejosat.960993)

ATIF/REFERENCE: Erdil, A. (2021). Development Supply Chain Management In Terms of Quality Function: An Application in the Manufacturing Industry. European Journal of Science and Technology, (26), 456-465.

\begin{abstract}
In terms of financial efficiency, customer loyalty, and partner earnings, Supply Chain Management (SCM) efficiently benefits the company. The belows are some of the corporate opportunities of supply chain management. It increases sales, helps to reduce capital expenditures in the industry, reduces time by making efficient use of the time between consumer orders and distribution and Improves responsiveness to changes in demand, increasing supply stability. Due to this topic, by combining Quality Function Deploymnet (QFD) applications with a SCM system, this research will provide the researcher with an improved output arrangement. It covers the basics of using QFD in SCM systems as well as several examples of how to use QFD as a continuity reference and a supply chain management approach. This research looks at how and why QFD can be used in a supply chain, as well as some of the potential applications. QFD technique may help with SCM implementations. Customers' importance in a supply chain network cannot be overstated. The integration of "Customers Voice" into the applied structure ensures a high chance of performance and device productivity, while the Fuzzy QFD implementation promotes strategic analysis as a framework for evaluating. Supply chain management is critical from a strategic standpoint and is seen as a competitive advantage. In this study, in the furniture industry, switching from conventional approaches to supply chain management with QFD has a number of benefits. The application's main objective is to expose the process and operation of supply chain management in the furniture industry in this context.
\end{abstract}

Keywords: Industry, Manufacturing, Quality Function, Supply Chain Management.

\section{Kalite Fonksiyonu Açısından Tedarik Zinciri Yönetiminin Geliştirilmesi: İmalat Endüstrisinde Uygulaması}

$\ddot{O ̈ z}$

Tedarik Zinciri Yönetimi (TZY) şirketlere finansal karlılık, performans, müşteri sadakati ve iş ortağı kazançları açısından verimlilik açısından fayda sağlar. Tedarik zinciri yönetiminin kurumsal açıdan sağladığı firsatlardan bir kısmı aşağıda belirtildiği gibidir. Bu fırsatlar şu şekilde sıralanabilir; firma satışlarını artırır, sektördeki sermaye harcamalarını azaltmaya yardımcı olur, tüketici siparişleri ile dağıtım arasındaki süreyi verimli kullanarak zamanı azaltır, talep değişikliklerine yanıt vermeyi iyileştirir ve arz istikrarını sağlar, artırır. Bu konuya bağlı olarak, Kalite Fonksiyonu Dağılımı (KFD) uygulaması bir işletmedeki Tedarik Zinciri Yönetimi (TZY) sistemi ile birleştirilerek, bu araştırma kapsamında bu uygulama alanı, sektörü için gelişmiş bir çıktı düzenlemesi sağlamaktadır. Bu araştırma, KFD yönteminin TZY sistemi ile birlikte kullanmanın temellerini ve ayrıca KFD’nin süreklilik birleşenlerini ve TZY yaklaşımı olarak nasıl kullanılacağına yönelik birkaç örnek kesitleri içermektedir. Bu çalışma, KFD'nin bir tedarik zincirinde nasıl ve neden kullanılabileceğinin yanında bazı potansiyel uygulamaların nasıl ve niçin kullanılabileceğini incelemektedir. KFD tekniği, TZY uygulamaları için yardımcı araç olarak kullanılmaktadır. KFD 'nin önemli bir unsuru olan "Müşterilerin Sesi"'nin (Voice of Customer) TZY'ne entegrasyonu, yüksek bir performans artışı ve üretkenliği sağlarken Bulanık KFD uygulaması, değerlendirme aşaması için yapısal açıdan stratejik analizi sağlar. TZY, stratejik açıdan kritiktir ve rekabet avantajı olarak işletme için önem arz eder. Bu çalışma kapsamında mobilya endüstrisinde yapılan uygulama, KFD ile geleneksel yaklaşımlardan tedarik zinciri yönetimin birlikte kullanılarak değerlendirilmesi sektöre üretim ve yönetim kapsamında faydalar sağlamıştır, sağlamaktadır. Uygulamanın temel amacı, bu bağlamda mobilya sektöründe tedarik zinciri yönetiminin sürecini ve işleyişini, KFD ve TZY yöntemlerini birlikte kullanarak sektöre yönelik TZY'ne yönelik iyileştirmeler sunmaktır.

Anahtar Kelimeler: Endüstri-Sanayi, İmalat, Kalite Fonksiyonu, Tedarik Zinciri Yönetimi.

* Corresponding Author: runesyalidre@gmail.com 


\section{Introduction}

A supply chain is the distribution of products, documents, finances, and services from raw material procurement to end customer though manufacturing plants. Many activities are included in a multi-layer and multi-product chain, including acquisitions, cash flow, thermal treatments, preparation and production management, inventory control and storage, and shipment and supply. The phase of implementing modern strategies to production and operations management suggests that there is a growing trend in the use of supply chain management techniques by different manufacturing companies and services, with the goal of reducing costs and enhancing market share and productivity. Supply Chain Management systems (SCMs) are recently developed, much research is being conducted and much is also being done. Competition in the global economy demands more and better performance for companies. The structures of Supply Chain Management (SCM) attempt at integrating and managing external productions and services of a company. This allows a company to evaluate the risks better, risk evaluation and reduced cost advantages (Individual or altogether). In the global marketplace, and for a company that uses SCM, evaluations need still stronger and better performance. The integration of various management, manufacturing and efficiency sciences into the method accomplish these objectives. These objectives are met by incorporating various administration, manufacturing, and efficiency sciences into the framework. The concept of quality feature use is aimed at defining consumer and business preferences by a range of tools and at integrating the customers' expectations into the current environment right from the start. (Monczka et al., 2016; Fazlollahtabar, 2018; Jacobs and Chase, 2018; Supply Chain Management Articles, 2021).

SCM has been a key concern for companies to lay the groundwork for sustainability to be achieved and sustained. Various methods have been created in recent decades to quantify and analyze the performances of the supply chain from different viewpoints. Supply chains are currently trying to find a means of overcoming the enormous obstacles of their supply chains with new solutions, regulations and tactics. Consequently, an efficient measuring performance method is in fierce competition by companies to help them achieve their corporate objectives by measuring the efficiency of their current scheme. Consequently, a highly demanded efficient performance assessment framework supports businesses by measuring the efficacy of their current tactics in implementing their market targets. Supply chain visibility is the concept to track the stages that parts, components or products go through from the manufacturer to their final destination. Its purpose is to improve and strengthen the supply chain by ensuring that all stakeholders, including the customer, can easily access relevant data (Cohen and Roussel , 2004; Jayaram et al., 2014; Fazlollahtabar, 2018; SearchErp, 2021).

Supply management comprises the pursuit of organizational objectives, which are those tasks that have a significant effect on the different strategic success. Most such long-term tasks should not be undertaken in turn, but should be consistent with the organization's broader mission and objectives. Routine, basic, or day-to-day choices that might have been part of conventional buying obligations are not covered by all these tactics. It is not a competitive obligation to arrange and monitor essential operating inputs on a regular basis. Supply control encompasses a wider range of concepts than buying. Supply management is a forward-thinking method to address the manufacturing capability which breaks from the conventional arm's-length or adversarial relationship with suppliers. It necessitates buying practitioners working closely with manufacturers designed to deliver world-class value and benefits to the customer (Monczka et al., 2016; Lysons, 2016; Jacobs and Chase, 2018; Supply Chain Management Articles, 2021).

The structure, implementation, and monitoring of performance that produce and distribute the business's key goods and services is referred to as operation and supply chain management (OSCM). OSCM, including accounting and marketing, is a practical industry area containing distinct line management positions. OSCM is required for the successful development of a system that manufactures a commodity or provides a service (Meredith and Shafer, 2016; Jacobs and Chase, 2018).

SCM refers to the coordination of all supply chain processes, starting with input materials and ending with a satisfied buyer. A supply chain, though, is made up of suppliers, manufacturers, and/or service providers, as well as sellers, suppliers, and/or retailers who can provide the goods and/or services to the final consumer (see figure 1). Numerous suppliers' approaches imply that, rather than focusing only on short-term incentives such as low cost, a consumer would be better off forming a long-term relationship with a few dedicated distributors. Long-term suppliers are most inclined to support the fundamental interests of the obtaining business and the end client. Reducing manufacturers will contribute positively by allowing manufacturers to stay viable and creating a learning curve that leads to lower procurement and production costs. This method also enables manufacturers to incorporate product advancements as well as technological expertise. The supply chain will generally be reinforced through locating activities in states with scarce activities. Human capital, low-cost labor, or raw materials are examples of commodities (Meredith and Shafer, 2016; Heizer et al., 2016; Jacobs and Chase, 2018).

The catalyst for supply chain optimization and international SCM would come through, or be supported by, upper management. This necessitates two-way coordination between upper management and the senior executives in charge of the interconnected supply chain or its functions and processes. The capacity to communicate the concept of an optimized supply chain to other team leaders, set and inspire the team to meet expectations, develop and recognize the potential, cultivate team members' competencies, promote a community of continual personal development, and demonstrate high standards of professional honesty are all essential leadership traits. The supply chain is the battleground. In general, this really takes resources to develop and operate an end-to-end supply chain company, but it also takes time, creativity, attention, focus, determination from senior executives, and a lot of strength to execute it off effectively. Notwithstanding, such are the characteristics shared by the world's best-run businesses, why they are at the top (Cohen and Roussel, 2004; Blanchard, 2010; Lysons, 2016)

This research would serve to provide the reader a better performance scheme by using QFD software in an SCM framework. It involves the fundamental use of QFD in SCM structures and brief detail on example experiments, including using QFD as a consistency guide and as a supply chain management strategy. 


\section{Material and Method}

\subsection{Concepts of Supply Chain Management (SCM) and Quality Fuction Deployment}

(i) Supply Chain Management (SCM): Supply chain management - the best place to supply the best thing, in the right time and at the right price - is one of the most effective forces to transform businesses. It is one of largest and most respected tactics for reducing costs and increasing sales. SCM attempts to integrate the internal system of the enterprise to its vendors, associates and customers at the time of transmission of trends which began with Business Process Reengineering, Total Quality Management and ERP, all of which tackled only the internal dynamics of an organisation. SCM is a flexible approach to follow thanks to technologies such as the Internet, electronic communication, shipping and warehouse management applications, including software that handles plant scheduling, market forecasting, and purchasing (Gunasekaran and Ngai, 2004; Ayers, 2006; Blanchard, 2010; Meindl and Capital, 2013; SearchErp, 2021)

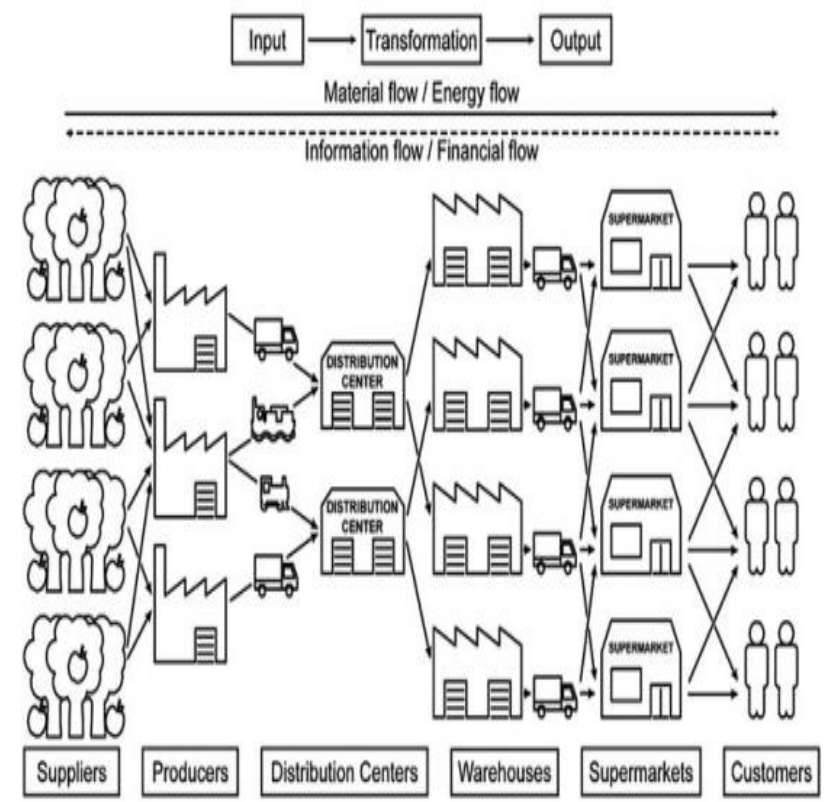

Figure 1. Supply chain Framework (Ivanov et al., 2016, p.5)

A supply chain of companies consisted of geographically distributed facilities, which purchase, process, stock, sell, and transport connections that bind the facility through which goods move. The supply chain included a supply chain. There is a distinction between factories where actual goods are converted and distribution centers where products are collected, sorted, stockpiled, stockpiled or stockpiled, and dispatched, but not processed physically. These facilities can be run by the business or by suppliers, customers, third-party contractors, or other companies for which the business has business agreements. The company's mission is to attach value to its goods as they move through it's own supply chain and deliver them to internationally diverse customers in the right quantities, with the right conditions, on schedule, and at a reasonable rate (Ayers, 2006; Blanchard, 2010; Chopra and Meindl, 2016; Ivanov et al., 2016; Meindl and Capital, 2013; see Figure 1).

Supply chain management effectively supports the firm in terms of financial performance, customer service and profits of partners. The benefits of supply chain management to the e-ISSN: 2148-2683 business can be summarized as follows. - It causes an increase in profits,

- It plays a role in reducing the capital used in the business, - It shortens the time by ensuring the effective use of the period from customers ordering to delivery. - Increases production flexibility by improving response to changes in demand, Ensures timely and complete preparation of customer orders, Increases quality by reducing product losses and faulty deliveries, - Maximizing the use of cash required by the enterprise by minimizing stock keeping, - Required information flow Ensures that the necessary steps are taken to ensure that product returns are made at a minimum level (Tanyaş, 2003).

(ii) Quality Function Deployment (QFD): Quality function deployment (QFD) is defined as "an overarching term that requires a certain level of converting consumer specifications into the required technical specifications with each phase of the design process and development (i.e., marketing strategy, preparation, product engineering and design, design assessment, manufacturing materials research, manufacturing, and purchases). The coordinator must sustain direct contact with the team member. Prior to the QFD process, the two must discuss the procedure, decide the complexity of the initiative, propose which organisations should be on the committee, evaluate the duration of the activities, and assist in the preparation of the opening paragraph outlining what is to be done and what is required for the resistance training to be efficient. What distinguishes QFD is that the main emphasis is on the needs of the consumer. The method is guided by what the consumer needs, not technological advancements. As a result, more time is expended in gathering the knowledge required to determine what the consumer actually desires (Bossert, 1990; Jagdev et al., 1997; What Is Quality Function Deployment, 2021).

Quality Function Deployment (QFD) is a versatile suite of product creation techniques developed in Japan to move quality management principles from the production phase into the modern product development process. The key characteristics of QFD are an emphasis on satisfying business needs through the use of specific customer comments (referred to as the "Voice of the Customer"), the efficient use of multidisciplinary collaboration, and the use of a robust matrix (referred to as the "House of Quality") for recording information, expectations, and decisions. Any of the advantages of implementing QFD were already reported as follows: According to Yoji Akao, QFD is a tool for designing a design quality directed at pleasing the customer and then turning the consumer's expectations into design goals and significant quality improvement criteria to be included in the development process. The primary characteristics of QFD are its emphasis on addressing consumer expectations by use of their based on the obtained (referred to as the "Voice of the Customer"), its improved communication of interdisciplinary team group project, and the use of a robust schema for recording facts, attitudes, and decisions. This matrix is sometimes pointed to as the "House of Quality" and is thought to reflect QFD through its totality (Bossert, 1990; Jagdev et al., 1997; Franceschini, 2001; Maritan, 2015).

The QFD process starts with our attempt to determine consumer specifications (or requires), which have been normally articulated in based on a qualitative characteristics, such as appealing to the eye, simple to use, functioning correctly, clean, long lasting, fashionable, convenient, and so on. Even during new product development, consumer expectations are gradually transformed through organizational requirement of the organization known as engineering standards. The organization 
assessment scheme is built on an optimal basis of QFD. QFD connects existing departmental operations to customer and other business objectives, creating a connection from personal responsibility to the practical skills (Bossert, 1990; Franceschini, 2001; Duffy et al., 2010; Maritan, 2015).

QFD begins by using voice of the customer (VoC) data to specify the customer requirements in the rows of the first house, the Output Planning Matrix. The name VoC stems from the fact that the customer's own language is used to capture these requirements. Next, based on the customer requirements listed in the rows, the technical requirements for the product or service are generated and listed in the columns of this house. While the customer requirements are expressed in the customer's own language, the technical requirements are often expressed in a more specialized language such as that used by engineers. Thus, technical requirements for a product might be expressed in terms of dimensions, weights, performance, tensile strength, and compression. An significant application of the matrix of ties seems to be to indicate that another or more technical criteria are fulfilled to each client. The partnership matrix should have been used to guarantee that the manufacturers do not apply to the product or service technological specifications which do not meet real customer needs. Developers who might not take consumer needs into account in particular continue exposing a certain amount of 'cells and whistles' that do not interest the customer. In such instances, the designers actually contribute to the expense of the finished good or service regardless increasing the value correspondingly. The construction of a quality house starts with the description of what developers intend to do in the rows over there on the left. The only first house is generally considered "Whats," which are either the consumer's needs or the consumer's voice. The next step is to worry about how these conditions can be satisfied after determining what we want to do. So, in the columns of the house are mentioned the "Hows," as they are named. The Hows are the technological specifications of the services or products provided when it comes to the first quality home. QFD is a range of platforms, one of the main advantages. Using QFD, a company is capable of analyzing its results as regards the wishes of its clients, comparing its results to the results of the rivals, determining whether it needs to best satisfy the expectations of each customer and determining how to do it. It also allows these consumer needs to be combined during the preparation period, concluding with comprehensive processes (Chan and Wu, 2002; Meredith and Shafer, 2007; Wang, 2015; What Is Quality Function Deployment, 2021);

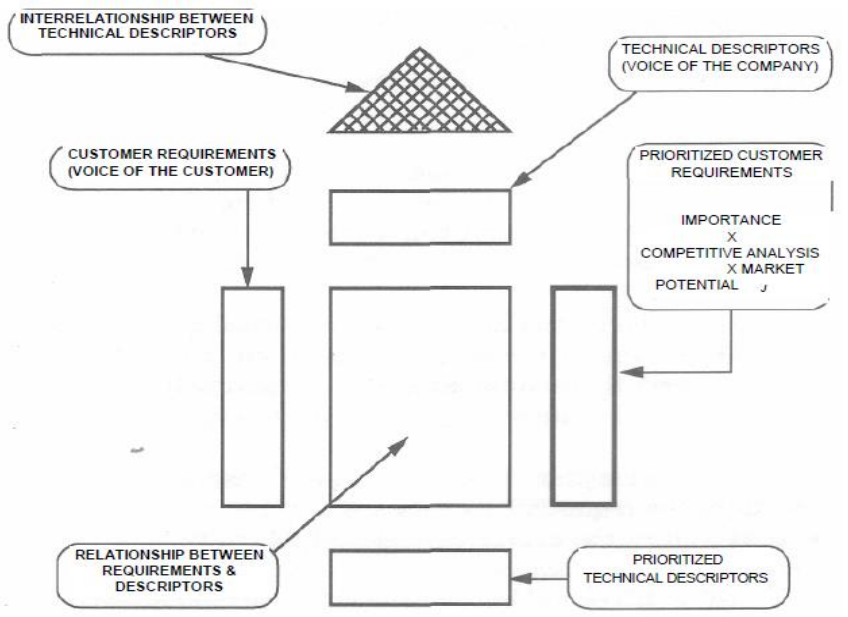

Figure 2. A Basic QFD Matrix Showing the Various Components (QFD Process Concept (House Of Quality) (Bossert, 1990). e-ISSN: 2148-2683
The most well-known type of QFD is the "House of Quality" matrix (see Figure 2). It is used by a multidisciplinary team to convert a range of consumer expectations into an acceptable number of priority development milestones to be fulfilled by a new product concept, based on market analysis and benchmarking results. This matrix comes in a variety of subtly different ways, and one of its main benefits is its ability to be tailored to the needs of a specific problem or community of users. The "House of Quality" is composed of six main components that are completed over the process of a QFD studies. These are as below (Franceschini, 2001; Chan and Wu, 2002; Meredith and Shafer, 2007);

Consumer requirements (HOWs) - a formal list of requirements based on customer comments.

Technical description (WHATs) - a standardized list of applicable and observable specific products.

Planning matrix - depicts consumer expectations gleaned from market research. Including the relative relevance of consumer needs, as well as the success of the firm and its competitors in completing specific.

Interrelationship matrix- depicts the QFD team's views between the interdependence of technological and consumer specifications. A suitable scale is used, and is represented with icons or numbers. Filling out this section of the matrix requires team meetings and policy development, which can be time intensive. Concentrating on core connections and reducing the amount of criteria are effective strategies for reducing resource requirements.

Interrelationship Between Technical Descriptors: Technological correlation (Roof) matrix - utilized determine where technical specifications help or hinder each other with the product development. Could draw attention to potential areas for creativity.

Strategic goals, metrics, and expectations - used to document the matrix's priorities for technological criteria, technical success measurements attained by competing goods, and the degree of complexity involved in developing each requirement. The matrix's actual version is a series of goal requirements with each technological condition to be fulfilled by the conceptual building that are related back to the employee's requirements.

\subsection{Literature Reviews}

In a period of global supply chain management (SCM), suppliers have difficult situations in which shippers are seeking alternatives to supply chain when waiting for reduced shipping prices. The report sets out useful recommendations for practical solutions for shipping firms. They will use the QFD-ANP technique to build the knowledge to translate the desire of consumers to their supply chain design specifications. As a case study of a cargo shipping company shows, it is appropriate to reach concurrently diverse requirements of commercial, social and environmental requirements. This research aims to create a safe shipping distribution network through rehabilitating clients. The focus of this research is to develop a reliable shipping supply chain by addressing consumer needs. This is done by integrating Quality Function Deployment (QFD) and Analytical Network Process (ANP) in an analytical framework for the implementation of shipping firms (Lam, 2015).

According to the research of logistics and supply chain management, customer support leadership in the new century is a quality management practices. Enterprises improve customer loyalty and earn market stakes by enhancing logistic efficiency. The purpose of this study is to provide an initial approach to 
customer relationship management. The method consists on QFD, a concept that's just been widely applied in the production of new materials. This study discussed the logistics and supply chain management potential application of QFD. In particular, an initial approach for a feasible strategy was suggested and implemented. The research examined the use of QFD in the field of logistics and supply chain management. In particular, an original approach to classify feasible strategic measures that a company might work to improve logistical efficiency was suggested and implemented. The technique evolved may properly be used as a valuable tool to pick the most appropriate logistical implements in terms of quality of service (Bottani and Rizzi, 2006).

SCM enables convergence with the existing customers, the delivery network, internal operations to companies and the supply base, thereby influencing SCM's operational efficiency, sustainability success and how it is viewed by the different stakeholders. The new pattern of globalisation, and the increased competition is the main focus for SCM, whereby SCM is well placed as a key management tool for the sustainability success of organisations, both external and internal stakeholders, ranging from raw material manufacturers to end consumers. Supply chain management (SCM) facilitates integration between the customer base, the distribution network, activities internal to firms and supply base, thus SCM practices highly influence organizational performance, sustainability performance and how this is perceived by the external stakeholders of firms. In the current trend of globalization and increasing competition, the strategic management of all external and internal stakeholders from raw material suppliers to end users is the primary focus for SCM, hence SCM is well positioned as an influential management method for sustainability performance of organizations (De Brito and Van, 2010; Reefke and Sundaram, 2017).

A structured dynamic data processing platform as an allinclusive monitoring and evaluation scheme, this paper attempts to dynamically evaluate the performance of a supply chain from a sustainable and resilient point of view. In addition, a hybrid approach is used to choose the best sustainable and resilient variables consistently using the proposed framework, using Quality Function Deployment (QFD) in conjunction with the Decision Making Trial and Evaluation Laboratory (DEMATEL), which would then be used in the data development review framework. The system is being used to show its strengths and usefulness in the automobile industry (Ramezankhani et al., 2018). Via a formal systemic analysis the Study sets out core topics, patterns and new opportunities for study. The systemic study provides descriptive research and a conceptual overview of state-of-the-art quality assurance, productivity and the literature on supply chain management (Bastas and Liyanage, 2018).

The research of Akao (1990) seeks to evaluate and advise suppliers on two issues, namely marketing specifications and technological capabilities by means of the consistency feature implementation- quality function deployment (QFD). In the analysis of Asadabadi (2017), the supplier's selection process is accomplished through a system integrated by analytical network process (ANP), QFD and a Markov Chain. This approach uses a chain of Markov to monitor and consider a trend for shifting customer requirements. Management of the sustainability supply chain is gathering momentum. Numerous reports suggest quantitative assessment methods for competitive supply chains management. This research suggests a model for community decision to choose sustainability management supply chain metrics. The proposed approach would be focused on the implementation of Hesitant Fuzzy Linguistic Term Sets (HFLTS) and the Quality House-Quality Function Deployment (QFD) process categorization technique. Concerning the selection of quality considerations in the supply chain, the final selection of indicators often considers the level of relevance of data gathering, measured based on language structure about available knowledge, staff and effort and time (Osiro et al., 2018). A well know methodological approach, Quality function Implementation (QFD) has a broad scope for efficiency, such as sustainable production of products, enhancement design and implementation processes. In this research, QFD is a standard method for the environmentally-conscious design process for the successful development of a sustainable supply chain. Any of the applied linguistics are Madu, Kuei and Madu (2002), Sakao (2007), Kuo, Wub, and Shieh (2009).

\subsection{Quality Function Deployment in Supply Chains Management Systems Application}

Seeing as QFD techniques are intended to define customer requirements and enhance design and development operations, they are targeted at customer needs. QFD is an excellent match for the supply chain framework. SCM helps to enhance a company's reputation with its suppliers and consumers by reducing complexity and enhancing regulation and configurability. QFD assists a company in orienting and focusing on consumers, which increases the overall supply chain performance (Temponi et al., 1999; Chan and Wu, 2002; Blanchard, 2010; Jacobs and Chase, 2018).

\subsubsection{Customers Voice in Supply Chains Application}

Quality Function Deployment (QFD) is a total quality management (TQM) delivery approach that requires a straightforward evaluation of client/end-user requirements in addition to the specific needs of a project in order to turn them into design goals. QFD is just one of the strategies for dealing with consumer demands and desires quite consistently in order to achieve a construction company's most critical goal, client satisfaction. QFD applications of supply chain management seek to improve supply chain performance by "gaining a competitive advantage" as mentioned previously. The QFD method helps in the construction of supply chains. It collects consumer survey responses in order to assess supply chain success. QFD addresses consumer desires and preferences more consistently in order to achieve a corporation's main critical goal, consumer loyalty. QFD is a complete operational excellence (TQM) delivery approach that requires a straightforward evaluation of client/end-user requirements in addition to the specific requirements of a design in order to turn them through technical specifications. The supply chain principle is focused on the transfer of knowledge, processes, and materials among a company and its service provider. As a result, various studies on QFD deployments have been conducted in order to define consumer needs and satisfy them by supply chain integration. Utilizing QFD software is critical for evaluating consumer preferences in supply chain through process development and evaluating the effectiveness of the supply chain network (Chan and Wu, 2002; Ayers, 2006; Meindl and Capital, 2013). 


\subsubsection{Fuzzy QFD techniques for optimizing supply chain goals}

Corporations must produce high-quality goods in order to succeed and thrive in the industry. A product does not have durability if it is just fault free; process quality other factors such as attractiveness, maintainability, and efficiency perceived usefulness; and, most importantly, a product would have the consistency that consumers expect. In other words, a commodity must fulfill the customer's needs. Unremarkable QFD applications seek to define the customer's need. However, because the optimal product characteristics cannot be calculated by the initial QFD.

It is necessary to acquire a new approach. The development group's challenge is to create quality requirements that meet the needs of the consumers. Typically, the management team conducts a research to assess the consumer's needs, and the results are a compilation of intangible Customer Attributes (CAs), such as "safe to be using," "effective," or "robust." Design considerations, on the other hand, are measurable and dependent on physical and mechanical properties. As a consequence of different currencies, branding and technology may disagree (Hauser and Clausing, 1988; Herrmann et al., 2006).

Fuzzy QFD, like standard Design process, utilizes specialists to describe output features and affordances, but instead of asking the professionals to provide predicted probabilities for criteria, Fuzzy QFD merely asks them to provide feedback through verbal parameters since this method of representation is generally mostly inevitable. For instance, instead of considering a set on a 5-point likert, professionals are forced to explain a connection between a success feature and a facilitators utilizing terms including weak or strong. Fuzzy QFD accepts the intrinsic complexity in definitions and the differences of neighboring explanations which occur in linguistic structure; thus, the use of fuzzy arithmetic and Monte Carlo simulation. This method, for instance, allows for the high likelihood through one person's definition of a successful relation being likely attributable to another person's interpretation of really strong on an overall level (Temponi et al., 1999; Sohn and Choi, 2001). Utilizing Fuzzy Quality Function Deployment (FQFD) technique, which addresses some methodological issues raised in traditional QFD and outshines some latest suggestions (Vanegas and Labib, 2001; Sohn and Choi, 2001).

\subsubsection{Through Decision-Making Utilisation Fuzzy QFD: Industrial Processing}

Quality Function Deployments (QFD) has been a well technique that is mostly used with product development process, but it has expanded into the applications and is also used as a multi-attribute decision-making tool. Fuzzy logic incorporates the uncertainty found in fact as well as the linguistic judgments of the organization's experts. It is viewed as a strategy that aids in the mathematical expression of the intermediate values found in real-world contexts. That's because the essence of industrial logistics is evolving through merely maintaining physical overstock to a condition where consumer demands cover both conventional warehousing and transportation practices as well as modern practices such as capacity building and preparation, product promotion, automated inventory control, and personalized investment banking. Manufacturers anticipate that manufacturing manufacturers can develop a certain brand and double as an advertising communication channel in relation towards being a supplier of products. The new manufacturing distributor would have to be dependable, adaptable, and expense all at the same time, which necessitates streamlined judgment (Dat et al., 2015; Osorio and España, 2020).

As previously said, an industrial company must conduct a model-based study of supplier companies. It is essential for the framework to accommodate both quantitative and qualitative data since both types of information are commonly used in informing real-world decisions; nonetheless, there are indeed some significant benefits to solving the issue is actually multiobjective existence utilizing linear programming techniques. Because all measurements in this framework are numerical, correctly translating descriptive method into a statistical framework is indeed a crucial requirement in the technique, and Fuzzy Quality Function Deployment (Fuzzy QFD) has been used for this intention (Erol, 2001). Prioritization of customer requirements and technological criteria that is effective and reliable will aid decision making in QFD and thereby increase competitiveness in product management accounting. To translate fuzzy sets into some kind of charging, Fuzzy QFD requires the fundamental framework of standard QFD including improvements. It is necessary to evaluate many features present in current issues by using a framework based on Fuzzy QFD interconnected judgments through an industrialized supplier's supply chain, involving facts which could be considered quantitative or qualitative as well as many priorities which could compete (Vanegas and Labib, 2001; Zhai et al., 2010).

\section{Results}

\subsection{Survey Study and Application}

In this part of the research, a quality function deployment (QFD) was implemented in this component of the analysis to obtain assessment of supply chain in terms of management, satisfaction, with the consumer and business expectation for the furniture manufacturers-producers in manufacturing industry. This application was evaluated via QFD and SCM together for furniture manufacturers-producers in manufacturing industry in Turkey

Furniture for furniture manufacturers-producers of manufacturing industry is indeed one of the fundamental essential commodities that individual is inextricably linked to and requires at all stages of the lifespan. Commercially, efficiency, reachability, and reasonableness are essential requirements for person in furniture. While it has yet to achieve a systematic and observable implementation field in the furniture industry, the importance of supply chain management is becoming more widely understood. Because this furniture industry does not use standardized raw materials and intermediary products, the supply chain is complex. Furniture generally takes shape according to its function and many natural and artificial materials are used in its production. Furniture; It is classified differently according to its function, type of construction, the place where it is used and the types of materials used in its production. The supply chain can be defined as the activities that include the supply of raw materials, production and assembly, storage, inventory control, order management, distribution, delivery of the product to the customer and the information systems required to monitor all these activities (Yaşar, 2005; Gürpınar, 2007). This research seeks to investigate the stage at which supply chain management approach with QFD role in the furniture industry, as well as what can be achieved in the future. 
The formulas for Quality of House with Quality Function Deploymnet are presented as below; The mentioned equations have been used to assess the absolute and relative grades of consumer needs that allow for the creation and establishment of technological characteristics of supply chain management (Garvin, 1987; Hauser and Clausing, 1998):

$$
A W_{j}=\sum_{i=1}^{n} \operatorname{IR}_{i j} \times W_{j}
$$

Absolute weight (AW): the weight (IW) and enhancement ratio (IR) increases grant everyone absolute weights in relation to the consumer requirements. The simple way in which the weight of the technical requirements can be calculated is to assign identifiers in the matrix (Hauser and Clausing, 1998; Garvin, 1987).

AWJ = Row vector of absolute weight to the technical level of technical complexity

$$
\mathrm{CNW}_{\mathrm{j}}=\frac{\mathrm{AW}_{\mathrm{j}}}{\sum \mathrm{AW}_{\mathrm{j}}} \times 100
$$

$$
\mathrm{j}=1,2, \ldots, \mathrm{m}
$$

Such that, In which:

IW = consumer demand weight in accordance with IRij

IR = improvement rate - weight for the matrix, weight for the matrix by row $\mathrm{i}$ and column $\mathrm{j} ; \mathrm{i}=1,2, \ldots, \mathrm{m} ; \mathrm{j}=1,2, \ldots \ldots, \mathrm{n}$ ) $\mathrm{m}=$ number of technological specifications; $\mathrm{n}=$ number of specifications for consumer.

The customer needs weight (the relative value of $\mathrm{CNW}$ ) that both collects absolute weights and divides them into one set, in order to give a standardized customer weight.

In this application; customer requirements, customer significance level and technical characteristics were determined and scored with the experts and employee of manufacturing industrial sectors (TUSIAD). Besides, a questionnaire was prepared for learning the opinions, perspectives of customers about the sustainability of supply chain management of manufacturing sector. This step of the study was very important to gather data and also to assist in the implementation of the research.
This survey was e-mailed to approximately 145 different corporations (large business and SME) of furniture manufacturers-producers in manufacturing industry in Turkey with the help of the Turkish Industrialists' and Businessmen's Association (TUSIAD) and Turkey Exporters Assembly (TIM).

The results of this questionnaire were assessed on the framework of sustainability via renewable energy sources such as environment-oriented energy consumption. The sample size was 91 , returning the survey from these companies in Turkey, with a $63 \%$ rate of response.

The results of this questionnaire were assessed on the framework of the fields of manuacturing engineering, customer satisfaction, quality, configuration and sustainability of Supply Chain Management of furniture manufacturers-producers of manufacturing industry.

The main objectives in terms of Customer Requirements (Voice of Customers-Whats) for furniture manufacturersproducers in manufacturing industry for this application are shown in Table 1.

Technical Characteristics-Requirements (TCs-TRs) for these characteristics which were determined according to quality and sustainability of supply chain management with Technical Criteria of manufacturers due to the experts of this fields-sector in Table 1.

Technical Criteria of Customer Relation Management for Manufacturing-Production Sector are shown in Table 1 as below. This table is prepared from interviews of the furniture manufacturers-producers, reports of these businesses, literature resources and experts of this industry (Sürdürülebilir Tedarik Zinciri Yönetimi, 2021; Tedarik Zinciri Görünürlüğü ve Müşteri Memnuniyeti, 2021; Tedarik Zinciri Sürdürülebilirliği Sürekli İyileştirme için Pratik Rehber, 2021; reports of business; experts' views etc.)

In order to create the QFD (Quality Function Distribution) diagram, Absolute weights (MA; Absolute weight-AW) for each technical requirements and Customer Requirement Weights (MGA; Customer need weight- CNW) calculated based on these absolute weights were calculated. The formulas in equation (1) and (2) were used in the calculation of the correlation values in the QFD matrix.

Table 1.Technical Criteria of Customer Relation Management for Manufacturing-Production Sector
1. Demand and stock management where risks are minimized.
2. Establishing a supplier structure where risks are minimized.
3. Monitoring of risky, critical and urgent material management with a separate process, Human Factors
Engineering in terms of Health- Production by Considering Ergonomic Criteria.
4. Structuring the purchasing organizational structure by considering the risks.
5. Establishing trust at all levels of the supply chain, Green Transport and Distribution Strategies.
6. Making internal customer and dental customer surveys, Reducing Inventory and Energy consumption.
7. Receiving feedback from purchasing employees periodically.
8. Eliminating the risk perception of supplier companies.
9. Establishing a relationship with suppliers on the win-win systematic, Shortening the Supply Cycle Time.
10. Determining the appropriate communication method by knowing the structure of each ring in the chain.
11. Designing every stage of the chain according to the standards, but providing sufficient elasticity according to the needs, Improving Delivery Performance.
12. Ability to take initiative for specified groups and levels, Improving Order Fulfillment Rate.
13. Flexibility in capacity usage and manageability of costs, Reducing the Carbon-Water-Energy Footprint. 
The quality function deployment applied from the feedbacks of interviews with experts of the corporations of manufacturing industry in Turkey are shown in Table 2 . Table 2 provides the interrelationship matrix with the type of relationships. Any cell that is empty implies no or insignificant relationship. The degrees of the strength of relationship are placed in the column of customer requirements and technical characteristics of quality function deployment matrix.

Table 2. Quality Function Deployment Table

\begin{tabular}{|c|c|c|c|c|c|c|c|c|c|c|c|c|c|c|c|}
\hline \multirow{2}{*}{ 离䓌 } & \multirow{2}{*}{ 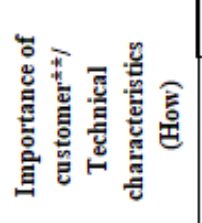 } & \multicolumn{13}{|c|}{ Technical Criteria } & \multirow{3}{*}{$\begin{array}{l}\mathrm{G} \\
\mathrm{e} \\
\mathrm{n} \\
\mathrm{e} \\
\mathrm{r}\end{array}$} \\
\hline & & c1 & c2 $\quad$ c & c3 & $\mathrm{c} 4$ & c5 & c6 & c7 & c8 & \begin{tabular}{|c|c} 
& $c$ \\
\end{tabular} & $\mathrm{c} 10 \mathrm{c}$ & c11 & $\mathrm{c} 12$ & $\mathrm{c} 13$ & \\
\hline $\begin{array}{l}\text { Procurement Cost, Loyal } \\
\text { Customer Price }\end{array}$ & 4 & 9 & 9 & 3 & 9 & 9 & 3 & 9 & 3 & 3 & 9 & 3 & 9 & 9 & \\
\hline $\begin{array}{l}\text { Customer satisfaction, Short } \\
\text { delivery Times }\end{array}$ & 4 & 3 & 9 & 9 & 9 & 9 & 1 & 9 & 3 & 3 & 3 & 9 & 9 & 9 & $\begin{array}{l}\mathrm{a} \\
1\end{array}$ \\
\hline $\begin{array}{l}\text { Providing supply human needs, } \\
\text { Delivery on time with the } \\
\text { requested quality }\end{array}$ & 4 & 3 & 3 & 3 & 3 & 9 & 3 & 3 & 3 & 3 & 9 & 9 & 9 & 9 & $\begin{array}{l}\mathrm{T} \\
0 \\
\end{array}$ \\
\hline $\begin{array}{l}\text { In terms of accident risks, } \\
\text { transparently sharing information } \\
\text { to gain customer's trust }\end{array}$ & 5 & 3 & 3 & 3 & 9 & 9 & 3 & 3 & 3 & 3 & 9 & 9 & 9 & 9 & $\begin{array}{l}\mathrm{l} \\
\mathrm{a} \\
1\end{array}$ \\
\hline $\begin{array}{l}\text { Improving and Strengthening the } \\
\text { Supply Chain by ensuring that all } \\
\text { stakeholders, including the customer }\end{array}$ & 5 & 3 & 3 & 3 & 9 & $9 \mid$ & 9 & 9 & 9 & 9 & 3 & 3 & 9 & 9 & \\
\hline Absolute Net Weight (MA) & & 90 & 114 & 90 & 174 & 198 & 88 & 144 & 96 & 96 & 144 & 144 & 198 & 198 & 1774 \\
\hline $\begin{array}{l}\text { Customer Requirement Net } \\
\text { Weight (MGA) } \\
\end{array}$ & & 5,07 & 6,43 & 5,07 & 9,81 & 11,16 & 4,96 & 8,12 & 5,41 & 5,41 \& & \begin{tabular}{|l|l}
8,12 & 8 \\
\end{tabular} & 8,12 & 11,16 & 11,16 & 100,00 \\
\hline Rank & & 11 & 8 & \begin{tabular}{|l|}
11 \\
\end{tabular} & 4 & 1 & 13 & 5 & $\begin{array}{l} \\
\end{array}$ & \begin{tabular}{|l|}
9 \\
\end{tabular} & 5 & \begin{tabular}{|r|}
5 \\
\end{tabular} & 1 & 1 & 18 \\
\hline
\end{tabular}

Table 3.The groups of the priority order for the Technical Requirements (Depending on the sorting (Rank) CNW-percentage value) from QFD Table

\begin{tabular}{|l|l|l|}
\hline $\begin{array}{l}\text { The priority } \\
\text { number- } \\
\text { importance (Rank) }\end{array}$ & $\begin{array}{l}\text { CNW- } \\
\text { percentage value }\end{array}$ & Technical Requirements \\
\hline $1(3)$ & 11,16 & $\mathrm{c} 5 ; \mathrm{c} 12 ; \mathrm{c} 13$ \\
\hline $2(4)$ & 9,81 & $\mathrm{c} 4$ \\
\hline $3(7)$ & 8,12 & $\mathrm{c} 7 ; \mathrm{c} 10 ; \mathrm{c} 11$ \\
\hline $4(8)$ & 6,43 & $\mathrm{c} 2$ \\
\hline $5(10)$ & 5,41 & $\mathrm{c} 8 ; \mathrm{c} 9$ \\
\hline $6(12)$ & 5,07 & $\mathrm{c} 1 ; \mathrm{c} 3$ \\
\hline $7(13)$ & 4,96 & $\mathrm{c} 6$ \\
\hline
\end{tabular}

As a result of this sorting, 3 units of technical characteristics $(\mathrm{c} 5 ; \mathrm{c} 12, \mathrm{c} 13)$ which are the first priority, were identified with a value of 11.16 percent; The second priority technical characteristic includes 1 unit of technical characteristics (c4) which were identified with a value of 9.81 percent, the third priority technical characteristic involves 3 unit of technical characteristics $(\mathrm{c} 7 ; \mathrm{c} 10, \mathrm{c} 11)$ which were identified with a value of 8.12 percent, so on (see Table 3 ).

\subsection{Discussion}

In addition to the competitive advantage brought by supply chain management, the ruthlessness of competition in today's conditions has led companies to consider the concept of sustainability together with the supply chain in order to make a 
difference. The furniture industry has a complex structure in terms of supply chain, the data obtained must be evaluated quickly and consciously and all processes must be kept under control. Especially in the furniture sector, it creates a professional supply chain of large companies.

Sustainable Supply Chain Management (SCM) meets the needs of stakeholders, including customers based on economic, environmental and social dimensions. With the Sustainable Supply Chain Management (SCM), it is ensured that more flexible processes are formed, environmentally protective packaging, reducing deadlines, and increasing the reputation of the company both in the customer and the society. Sustainability of Supply chain is the management of environmental, social and economic impacts of products and services throughout the life cycle and the promotion of good governance practices. The purpose of supply chain sustainability is to create, protect and develop long-term environmental, social and economic values for all stakeholders involved in the process of bringing products and services to the market. Companies that improve the sustainability performance in their supply chains reduce their risks, increase their efficiency, increase their innovation capacity and reinforce their corporate values. An evaluation of all processes of the supply chain management via QFD in the furniture industry comprises the innovation cycle, supply chain entities, procurement and manufacturing processes, distribution processes, marketing and sales processes and the customer support processes. Despite several research on the wood processing industry, there are unusual cases in the field of furnishings concerning the consequences of supply chains.

\section{Conclusions and Recommendations}

The aim of this research is to present the consumer and technical requirement-criteria about the SCM and the application of SCM with QFD. It offers short explanations on the use of QFD on a supply chain management system to boost efficiency and also provides details and background. Also the study was intended to provide a better performance framework for the learner using a QFD technique in an SCM context. It involves the fundamental use of QFD in SCM systems and brief details regarding analysis research and the use of QFD mostly as quality tool and as a policy support method in supply chain operations.

This study investigates how and why to incorporate QFD in a supply chain, as well as what certain applications it might have. SCM implementations may benefit from QFD methodology. The significance of customers in a supply chain network cannot be overstated. QFD incorporation incorporates "Customers Voice" into the implemented framework, ensuring a high probability of success and system efficiency, while Fuzzy QFD application supports strategic thinking as a framework for analyzing. Supply chain management has a strategic importance and is considered an important element in competition. The transition to supply chain management with QFD in the furniture industry based on traditional methods provides various advantages. In this context, the main purpose of the application is; to reveal the structure and functioning of supply chain management in the furniture industry. Using the full quality strategy in SCM systems is complementary but QFD is an essential instrument for the SCM implementation, since the consumer is by definition an internal member of the supply chain network. QFD can also be regarded as an obligatory component of any effective execution of the supply chain. A detailed inspection planned specifically for the QFD process is also important. The requirements and expectations of a customer are the starting point for industrial design. A detailed survey of consumer preferences is absolutely important in this respect. The collaborative process will improve a wide variety of choices on various weighting factors as part of the House of Quality configuration. Mostly a major element is a thoroughly developed for the QFD operation. What the customer wants and needs is the ultimate destination for manufacturing. A robust consumer wishes questionnaire is absolutely important in this respect. The healthcare professionals will make a large number of decisions on various weighting parameters component of the Quality Channel.

\section{Acknowledge}

I would like to thank the business executives, furniture industry employees and experts who shared their valuable knowledge for the study and contributed to the research by participating in the survey-literature research within the scope of work.

\section{References}

Akao, Y. (1990). Quality function deployment: integrating customer requirements into product design. Springer, Cambridge, MA.

Asadabadi, M. R. (2017). A customer based supplier selection process that combines quality function deployment, the analytic network process and a Markov chain. European Journal of Operational Research, 263(3), 1049-1062. doi:10.1016/j.ejor.2017.06.006

Ayers, J.B.(2006) Handbook of Supply Chain Management, Auerbach Publications; 2nd edition (April 24, 2006), 640 p.

Bastas, A. and Liyanage, K. (2018). Sustainable supply chain quality management: A systematic review. Journal of Cleaner Production, 181, 726-744. doi:10.1016/j.jclepro.2018.01.110

Blanchard, D. (2010). Supply Chain Management Best Practices, Second Edition, 303 p., ISBN 13:9780470531884.

Bottani, E., and Rizzi, A. (2006). Strategic management of logistics service: A fuzzy QFD approach. International Journal of $\begin{array}{lll}\text { Production } & \text { Economics, } & \text { 103(2), }\end{array}$ doi:10.1016/j.ijpe.2005.11.006

Bossert, J.L (1990). Quality Function Deployment: The Practitioner's Approach (Quality and Reliability Series, Volume 21), CRC Press, 125 p., ISBN 13: 9780824783785.

Bossert, J.L (1990). Quality Function Deployment: The Practitioner's Approach (Quality and Reliability Series, Volume 21), CRC Press, 125 p., ISBN 13: 9780824783785 p.7

Chan, L.-K. and Wu, M.-L. (2002). Quality function deployment: A literature review. European Journal of Operational Research, 143(3), 463-497. doi:10.1016/s0377-2217(02)00178-9

Chopra S. and Meindl P. (2016). Supply Chain Management Strategy, Planning and Operations, South-Western College/West-Pearson, 6 th Edition, 890 p., ISBN 13: 978-1-285-86968-1

Cohen, S. and Roussel, J. (2004). Strategic Supply Chain Management, First Edition, McGraw-Hill, 339 p., ISBN 13: 9780071454490.

Dat, L. Q., Phuong, T. T., Kao, H.-P., Chou, S.-Y. and Nghia, P. V. (2015). A new integrated fuzzy QFD approach for market segments evaluation and selection. Applied Mathematical Modelling, 39(13), 3653-3665. doi:10.1016/j.apm.2014.11.051.

De Brito, M.P. and Van der Laan, E.A. (2010). Supply chain management and sustainability: procrastinating integration in 
mainstream research. Sustainability, 2, 859-870. https://doi.org/10.3390/su2040859.

Duffy, G.L., Moran, J.W. and Riley, W. J. (2010). Quality Function Deployment and Lean-Six Sigma Applications in Public Health, First Edition, ASQ Quality Press, 218 p, ISBN 13: 978-0-87389787-7

Fazlollahtabar, H. (2018). Supply Chain Management Models: Forward, Reverse, Uncertain, and Intelligent Foundations with Case Studies, First edition, CRC Press, 401 p., ISBN 10: 1351336576

Franceschini, F. (2001), Advanced Quality Function Deployment, First Edition, CRC Press, 209 p., ISBN 13: 9781574443219.

Garvin, D. A. (1987), Competing on the Eight Dimensions of Quality, Harvard Business Review, November/December, p. 101-109

Gunasekaran, A. and Ngai, E. W. (2004). Information systems in supply chain integration and management. European Journal of Operational Research, 159(2), 269295. doi:10.1016/j.ejor.2003.08.016

Gürpınar, K. (2007). Türk Mobilya Sektörünün Rekabet Gücü Üzerine bir Araştırma, Doktora Tezi, Afyonkarahisar Kocatepe Üniversitesi Sosyal Bilimler Enstitüsü.

Hauser, J. and Clausing, D. (1988). The House of Quality, Harvard Business Review, 16(1), pp. 63-73.

Herrmann, A., Huber, F., Algesheime, R., and Tomczak, T. (2006). An empirical study of quality function deployment on company performance. International Journal of Quality and Reliability Management, 23(4), 345-366. doi:10.1108/02656710610657576.

Heizer, J., Render, B. and Munson, C. (2016). Operations Management: Sustainability and Supply Chain Management (12th Edition), Pearson, 918 p., ISBN 13: 9780134130422.

Ivanov, D., Tsipoulanidis, A. and Schönberger, J. (2016). Global Supply Chain and Operations Management, chapter 1, Basics of Supply Chain and Operations Management, pp 1-14.

Jacobs, F.R. and Chase, R.B. (2018). Operations and Supply Chain Management, 15th edition, McGraw Hill, 785 p., ISBN 13: 978-1259-66610-0.

Jagdev, H., Bradley, P. and Molloy, O. (1997). A QFD based performance measurement tool. Computers in Industry, 33(2-3), 357-366. doi:10.1016/s0166-3615(97)00041-9

Jayaram, J., Dixit, M. and Motwani, J. (2014). Supply chain management capability of small and medium sized family businesses in India: A multiple case study approach. International Journal of Production Economics, 147, 472485.https://doi.org/https://doi.org/10.1016/j.ijpe.2013.08.016.

Kuo, T. C., Wub, H. H. and Shieh, J. I. (2009). Integration of environmental considerations in quality function deployment by using fuzzy logic. Expert Systems with Applications, 36, 71487156.

Lam, J. S. L. (2015). Designing a sustainable maritime supply chain: A hybrid QFD-ANP approach. Transportation Research Part E: Logistics and Transportation Review, 78, 70-81. doi:10.1016/j.tre.2014.10.003.

Lysons, K. (2016), Procurement \& Supply Chain Management, TransAtlantic Publ. (Pearson), 9th, 692 p., ISBN 13: 9781292086118.

Madu, C. N., Kuei, C. H. and Madu, I. E. (2002). A hierarchic metric approach for integration of green issues in manufacturing: A paper recycling application. Journal of Environmental Management, 64, 261-272.

Maritan, D. (auth.) (2015), Practical Manual of Quality Function Deployment, Springer International Publishing, First Edition, 199 p., ISBN 13: 978-3-319-08521-0

Meindl, P. and Capital, K. (2013). Supply Chain Management, Strategy, Planning, And Operation, Fifth Edition, Pearson, 559 p.

Meredith, J.R. and Shafer, S. M. (2016), Operations and Supply Chain Management for MBAs, Wiley, 6th Edition, 374 p., ISBN 13: 978-1-119-23953-6.

Meredith, J.R. and Shafer, S.M. (2007). Operation Management for MBAs, John Wiley \& Sons Inc., 416 p.

Monczka, R. M., Handfield, R.B., Giunipero, L.C. and Patterson, J.L. (2016). Purchasing and Supply Chain Management, 6th edition,
890 p., South-Western College/West, ISBN 13:978-1-285-869681

Osorio Gómez, J. C. and España, K. T. (2020). Operational Risk Management in the Pharmaceutical Supply Chain Using Ontologies and Fuzzy QFD. Procedia Manufacturing, 51, 16731679. doi:10.1016/j.promfg.2020.10.233.

Osiro, L., Lima-Junior, F. R. and Carpinetti, L. C. R. (2018). A group decision model based on quality function deployment and hesitant fuzzy for selecting supply chain sustainability metrics. Journal of Cleaner Production, 183, 964-978. doi:10.1016/j.jclepro.2018.02.197.

Ramezankhani, M. J., Ali Torabi, S. and Vahidi, F. (2018). Supply Chain Performance Measurement and Evaluation: A Mixed Sustainability and Resilience Approach. Computers \& Industrial Engineering. doi:10.1016/j.cie.2018.09.054.

Reefke, H. and Sundaram, D. (2017). Key themes and research opportunities in sustainable supply chain management identification and evaluation. Omega, 66, 195-211. doi:10.1016/j.omega.2016.02.003

Sakao, T. (2007). A QFD-centred design methodology for environmentally conscious product design. International Journal of Production Research, 45(18), 4143-4162.

SearchErp, supply chain visibility (SCV), https://searcherp.techtarget.com/definition/supply-chain-visibilitySCV (Acess Time: 29.04.2021).

Sohn, S. Y. and Choi, I. S. (2001). Fuzzy QFD for supply chain management with reliability consideration. Reliability Engineering \& System Safety, 72(3), 327-334. doi:10.1016/s0951-8320(01)00022-9.

Supply Chain Management Articles, https://www.fish bowl inventory.com/supply-chain-management (Access Time: 23.04.2021).Sürdürülebilir Tedarik Zinciri Yönetimi, http://www.mikado consulting.com/egitim/15/surdurulebilirtedarik-zinciri-yonetimi (Access Time: 12.04.2021).

Tanyaş, T.(2003). "Lojistik ve Tedarik Zinciri Yönetimi", Lojistik Dergisi, 3(15), p. 32

Tedarik Zinciri Görünürlüğü ve Müşteri Memnuniyeti, Tugay Gülerhttps://satinalmadergisi.com/tedarik-zinciri gorunurlugu-vemusteri-memnuniyeti/amp/ (Access Time: 12.04.2021).

Tedarik Zinciri Sürdürülebilirliği Sürekli İyileştirme için Pratik Rehber,https://d306pr3pise04h.cloudfront.net/docs/issues_doc\%2 Fsupply_chain\%2FSupplyChainRep_TR.pdf

Temponi, C., Yen, J. and Tiao, W. (1999). House of quality: A fuzzy logic based requirement analysis. European Journal of Operational Research, 117, 340-354.

Vanegas, L. V. and Labib, A. W. (2001). A Fuzzy Quality Function Deployment (FQFD) model for deriving optimum targets. International Journal of Production Research, 39(1), 99 120. doi:10.1080/00207540010005079.

Zhai, L. Y., Khoo, L. P., and Zhong, Z. W. (2010). Towards a QFDbased expert system: A novel extension to fuzzy QFD methodology using rough set theory. Expert Systems with Applications, 37(12), 8888-8896. doi:10.1016/ j.eswa. 2010 06.007

Wang, C.-H. (2015). Using quality function deployment to conduct vendor assessment and supplier recommendation for businessintelligence systems. Computers \& Industrial Engineering, 84, 24-31. doi:10.1016/j.cie.2014.10.005

What Is Quality Function Deployment (Qfd)? https://asq.org/ qualityresources/qfd-quality-function-deployment (Access Date: 23.03.2021).

Yaşar, S. (2005). Panel Mobilya Üretim Planlama Uygulaması, Yüksek Lisans Tezi, Gazi Üniversitesi Fen Bilimleri Enstitüsü, 5-8.

Y1lmaz, H. (2009). Optimization of the product design through Quality Function Deployment (QFD) and Analaytical Hierarchy Process (AHP): A case study in a ceramic washbasin, Yüksek Lisans Tezi, İzmir Yüksek Teknoloji Enstitüsü, Mühendislik ve Fen Bilimleri Enstitüsü, $91 \mathrm{p}$. 